\title{
Gender and Technoscience': A Historical Perspective
}

\author{
Pnina Geraldine Abir-Am²
}

\begin{abstract}
This paper explores turning points in the historical relationship between gender and technoscience, most notably the gender parity of the 2009 Nobel Prizes; the public debate on the under-representation of women in science that raged world-wide but especially in the US during 2005-2006; and the construction of a public memory for a leading woman technoscientist in the mid-1990s. The paper situates these turning points in the context of historical events, most notably the Scientific Revolution of the $17^{\text {th }}$ Century, WW2 and the Cold War, the women's liberation movement of the 1970s that legally ended overt gender discrimination, and the rise of covert gender discrimination since the 1990s. It concludes by highlighting the shift toward interactiveness and fluidity in the theoretical conceptions of both gender and technoscience.
\end{abstract}

Keywords: covert discrimination; gender; history; parity; power relations; public memory; technoscience; women scientists.

\footnotetext{
I "Technoscience" indicates the pertinence of a continuum between science and technology, covering natural, medical, and engineering sciences; it further captures the nexus of technology and science in areas of innovation that matter most nowadays, such as Biotech and ICT.

2 Women's Studies Research Center, (WSRC) Brandeis University, MS 079. 5 I 5 South Street, Waltham, MA, 02454, USA.

Phone: 00I-78I-736-8II9, Fax: 00I-78I-736-8II7. E-mail: pninaga@brandeis.edu, Website: http://www.brandeis.edu/centers/wsrcl scholars/Abir-Am.html
} 


\section{Introduction: "Turning points" in the Recent History of Gender and Technoscience}

"Turning points" can be conceived of as public moments of consciousness-raising, or instances of coalescing public awareness about a particular societal problem, which signal a pivotal change from the way a relationship, such as that between gender and technoscience, had been previously understood. The live and global Nobel Prize ceremony on 12-12-2009, when that most prestigious award reached gender parity for the first time in its century-long history ${ }^{3}$, emerged as the most recent "turning point" in the historical relationships between gender and technoscience. The 2009 Nobel Prizes constitute a turning point because they signaled that gender parity could be reached in the reward system at the very highest echelons of technoscience.

This paper will focus on a number of such "turning points", so as to better chart the recent history of the relationship between gender and technology. Among them is the public debate on the under-representation of women in science that raged during 2005-06 and created wide public awareness of a problem long observed, discussed, and monitored in science policy circles. Despite various interventionist measures by governments since the affirmative action legislation in the 1970s, and despite steady growth of women's enrollment at the level of scientific education, women scientists tend to drop out of scientific careers, especially at the higher levels. Indeed, the debate that erupted in 2005 began with an attempt to blame women's nature and culture, rather than the discriminatory institutions of technoscience, for the much lamented outcome of "leaky pipelines".

The last "turning point" to be examined is the discovery by this author that gender operates so as to exclude women not only from the practice of technoscience, especially at the higher levels of a scientific career, but also from its cultural memory. A case study, based on documentation from both the mid-1990s and the early 1980s, illustrates how male colleagues persisted in viewing a distinguished woman scientist through distinctive filters of gender (in the

${ }^{3}$ Gender parity in 2009 pertained to the combined fields of chemistry, biology, economics, and literature (but not physics). The institution of the Nobel Prize, which started to award annual prizes in 1900 is in itself a quintessential case-study in the cultural politics of technoscience. (see Friedman 200I) On the paucity of women as Nobel laureates see McGrayne 1998.
'First World'), class (in the 'Second World') or race (in the 'Third World'). They ignored her concrete scientific accomplishments by dissolving or reducing them to talents in the areas of sociability, family, and comportment, all traditional feminine attributes, derivative of her gender but totally irrelevant for clarifying her scientific prowess.

The focus on several such "turning points" complements previous studies of gender in science and/or technology that grappled with the relationship between gender and technoscience since the 1980s (e.g. Rossiter, 1982, 1995, Abir-Am, Outram, eds. 1987; Haraway, 1989, 1997; Etzkowitz et al, 2000; Lerman et al, eds. 2003; Bray, 2007; Wajcman, 2007) by illuminating lacunae such as the historical origins of public debates on gender in technoscience and their policy lessons (see sections 2 and 3) or the symbolism of the cultural memory of technoscience, or the Nobel Prize in an age of e-media (section 4).

Ever since the rise of modern science in the $17^{\text {th }}$ Century, the relationships between gender and technoscience have been defined by an "existential tension" that manifested itself in two complementary ways. On the one hand, practitioners of technoscience justified their increasingly prestigious occupation as a progress-oriented conquest of nature. Since nature was given attributes of the female gender, technoscience construed itself as a "vocation" of the male gender. On the other hand, actual women, however learned, were excluded from the new institutions of technocience. In later historical periods, women were marginalized, a practice that continues well into the present. For the last half a century no woman was included among the recipients of the Nobel Awards in Chemistry or in Physics.

Historians have clarified how the need of the practitioners of the new technoscience to distance their new synthesis of formerly separated artisanal and philosophical traditions from competing cultural systems at a time of great religious and political turmoil, led to a distancing between technoscience and the (female) gender. (Merchant, 1980;

\footnotetext{
${ }^{4}$ The 2009 Nobel Prize in chemistry for the discovery of the ribosome structure and its application to drug design, shared by Ada E. Yonat, was the first such award to a woman since Dorothy Hodgkin received the Nobel Prize for chemistry in 1964, and Maria Goeppert Mayer shared the Nobel Prize in Physics in 1963. During that period, half a dozen women shared the Nobel Prize in Physiology.
}

ISSN: 07I 8-2724. (http://www.jotmi.org)

Journal of Technology Management \& Innovation () Universidad Alberto Hurtado, Facultad de Economía y Negocios 
Keller, 1985; Haraway, 1989, 2004; Jordanova, 1989, Schiebinger 1989; Kohlstedt and Longino, eds. 1997) Though historically contingent upon the new science's need to distance itself from other traditions, such as the hermeneutic one which had focused on the female gender as a source of great symbolic power (an association which became problematic during the mass hysteria of witch hunting in the $17^{\text {th }}$ Century), the tension between gender as a constitutive force in the creation of a new cultural space for experimental philosophy (as "science", a $19^{\text {th }}$ Century term, was known at its birth in the $17^{\text {th }}$ Century), and the institutions of technoscience has continued until recently, when the highest echelons of technoscience began advocating gender parity as a social goal and policy objective (NAS 2006, 2009).

On the one hand, gender became a metaphor for the instrumental objectification of nature by the new seekers of nature's "secrets" who thus made "discoveries". On the other hand, the new institutions of technoscience such as the Royal Society of London, and the Académie des Sciences in Paris, both established by Royal Charters in the 1660s, explicitly excluded women practitioners from the then newly emerging community of technoscientists. In later generations, those who benefited from these practices - the "gentlemen of science" (self description for the founders of the British Association for the Advancement of Science in 1830) - extended this exclusion to all the new institutions of technoscience, its variety of capital and provincial academies, disciplinary societies, national associations for the advancement of science, and academic departments.

The establishment of women's colleges in the last third of the 19th Century (e.g. Girton in Cambridge, UK in 1869) and women's top ranking in the ancient universities' prestigious examinations began challenging the arguments on women's unsuitability for scientific education. Those arguments were intertwined with key legal and political restrictions, such as owning property, or the right to vote, the former until the 1880 s and the latter until 1920 .

Despite a long history of formal exclusion, women found ingenious ways of circumventing the formal prohibitions on their participation, thus counteracting the widespread beliefs in the unsuitability of their gender for technoscientific endeavors. Initially, they began contributing to science as members of a scientist's household (for example Caroline Herschel, who discovered several comets, was the daughter and sister of UK's Astronomer Royals); especially since until mid- and late-1 $19^{\text {th }}$ Century a great deal of science was still done from a home basis (Abir-Am and Outram, eds. 1987//989).

Other women managed to do science by seeking enlightened mentors, travelling to educationally less restrictive countries, limiting their familial responsibilities, founding institutions for single sex education, and gravitating toward scientific disciplines whose cultural imagery was in tune with their social roles, e.g. botany, or those which depended on large scale projects and low paid humanpower (e.g. astronomy) (Rossiter, 1995; Abir-Am, Outram, eds. 1987). Still others collaborated with their husbands, while struggling to establish islands of egalitarian partnerships, in a patriarchal ocean of technoscience, whose social power continuously increased (Pycior, Slack, and Abir-Am, eds. 1996).

Women's increasing participation in technoscience, however informal and limited, was crucial for combating social stereotypes that relegated them to the domestic or private sphere, as well as for challenging "scientific theories" that denigrated their biology and the suitability of their gender for technoscientific endeavors. Indeed, much of the early work of historians of women and gender in technoscience amounted to excavating the records and achievements of marginalized women whose actual role in making discoveries and inventions remained obscured.

The current relationship of gender and technoscience can be traced most directly to the settlement of WW2, which lasted between 1945 and 1989 with the ending of the Cold War. Embodied in inventions that affected the outcome of WW2, (the second most techoscientific war in the $20^{\text {th }}$ Century after the Cold War) most notably the atomic bomb, technoscience became the basis of great social and political power for technoscientists. The best known among them, Robert Oppenheimer and Edward Teller in the US, Andrei Sakharov in the former SU, Solly Zuckerman in UK, Frederic Joliot-Curie in France, Niels Bohr in Denmark, among others, became "technoscience advisers" while exerting great influence on the national military-industrial complexes that expanded to sustain the international balance of power (Abir-Am 20l0). Even though women contributed to the war effort, taking part in all aspects of the "Manhattan Project" that produced the 
most iconic of WW2 winning inventions - the atomic bombs (Howes and Herzenberg, 1999), as well as participating in post-WW2 major technoscientific projects such as the international geodesical year in 1957 (Fischer, 2005), their contributions were often obscured. In the last two decades women historians have proceeded to rescue such contributions ${ }^{5}$.

Though gender discrimination was relaxed during WW2 (and WWI), when national survival seemed to require that these forms of inequality be abandoned, at least for the duration of the war, once the war ended, gender, much as class and race, continued to function as a pillar of social inequality. The liberation movements of the 1960s and 1970s directly challenged and delegitimized inequality on grounds of race and gender. In the case of gender, it is common to regard the affirmative action legislation of 1972 and onward as the turning point that signaled the end of formal gender discrimination by outlawing discriminatory practices, especially educational and employment quotas. (Rossiter, 1995) This legislation, coupled with the women's liberation movement, perhaps best symbolized by the 1977 convention of 20,000 women that articulated gender solidarity as a major platform for social change, created a new generation of educated and liberated women with aspirations and abilities to achieve gender equality within the fields of technoscience.

However, the consciousness-raising process that helped liberate women in the 1970s and beyond, leading to establishing gender as a most powerful analytical category for historians (Green and Troup, 1999), often skipped the men, who continued to occupy the vast majority of technoscientific positions (Bix, 2000, 2004). A recent $50^{\text {th }}$ anniversary issue of the Society for the History of Technology (the October 2009 volume of its international quarterly, Technology and Culture) had no article or review on gender in relation to technology, including perhaps instead, an essay on technical education in the Third World. It would seem that most (male) historians of technology are not interested in gender andhave contributed little to combating gender stereotypes, while

\footnotetext{
${ }^{5}$ Considerations other than gender also played a role in defining the public perception of scientists in WW2, e.g. physicists enjoyed greater acclaim than chemists and engineers, whose participation was equally important. There is also contention around assessing the credit for the scaling up of inventions across countries, e.g. radar, which was produced in UK but was scaled up in the US for use in allied planes.
}

long advocating various levels of technoscientific determinism, (often as a professional strategy) well beyond gender issues.

By contrast, women historians of technology and feminist theorists of gender assumed almost entirely the burden of revising the technological determinism that became a hallmark of the history of technology, once it separated from the history of science in 1957 (when the Society for the History of Technology separated from the Society for the History of Science, which began in 1924). These scholars demonstrated how a variety of key technologies (e.g. cars, computers, ovens, steam laundering, dress making) were social constructions that changed historically rather than being fixed categories that impact users but are not impacted by them (Lerman et al, eds. 2003; Rothschild (ed.), 1983; Cowan, 1983; Bray, 2007; Wajcman, 2007). By shifting the center of gravity from producers to users, while highlighting the latter's crucial role in determining the fate of various technologies, women historians of technology liberated the history of technology from its exclusive focus on glorified inventors. They further highlighted the key role of gender in constraining design, other technical practices, and indeed in what counts as "technical".

At the same time that the concepts of technology, science, and technoscience underwent major theoretical shifts away from fixity and toward fluidity and interactiveness with society, the concept of gender, especially gender in technoscience, has also developed in a similar direction with initial notions of gender essentialism giving way to a more malleable concept of gender as both impacting and being impacted by technoscience (Bray, 2007; Wajcman, 2007; Lerman et al, eds. 2003; Haraway, 2004; Grint and Gill, eds. 1995).

The theoretical debates on the relationship between gender and technoscience occurred in a context of a rapid rise in the number of women graduates from institutions of higher learning since the 1970s, when formal discrimination was legally terminated. With parity being reached in the general undergraduate population, as well as in most professional schools (e.g. law, medicine, business, but not engineering), the lack of qualified candidates ceased being an acceptable reason for not hiring women. However, it soon became clear that these increased numbers of women in technoscientific education were 
rarely seen at the higher ranks in industry or in tenured slots in universities. The higher the rank, the fewer the women, a phenomenon dubbed the "glass ceiling". Among the various explanations offered for this phenomenon, one finds a variety of structural conditions, such as the lack of critical mass, lack of mentorship, lack of a balance of networking "ties", and the "chilly climate", all persisting conditions that proved difficult to address. (NRC, 1991; NSF, 1997; Valian, 1998; Etzkowitz et al, 2000; Rosser 2004; Fox, Johnson, Rosser, eds. 2006, Rayman et al, 2008)

Recent findings suggest that gender equality is more easily achieved in new technoscience fields such as biotech (but not in information and communication technology or ICT, Corneliussen, 2009), in part because its need for constant innovation requires a constant influx of new talent. Such organizations are willing to enable the sort of workplace flexibility that is crucial for people who must combine work and primary care for family members. The careers of such people, most often women, are often obstructed in hierarchical organizations such as universities and largescale industry, but flourish in small start-ups and mediumsize firms (Smith-Doerr, 2006).

Women's under-representation in science had been identified as a problem per se in the late 1980s and early 1990s. With the ending of the Cold War, fears of an imminent shortage in technoscientific humanpower (NRC, 1991; Abir-Am, 1992; NSF, 1997) led to policy efforts to improve the recruitment and retention of women. In that context of a global change from super-power confrontation to a multi-centered globalization, it seemed that a solution to the rising humanpower shortage in technoscience might be reached by encouraging more women not only to pursue technoscientific careers, but to be retained by the institutions of technoscience Still the "pipeline" continued to "leak" women, despite a variety of interventions, such as NSF funded special programs for women and minorities.

The social change brought about by the elimination of overt discrimination, mostly in the form of entry barriers, did not bring about a systemic change in science, let alone gender parity. Instead, a rather sophisticated form of covert discrimination developed, which effectively continued to limit the professional advancement of women. The covert discrimination proved very powerful because the "liberated" women and their enlightened man supporters were totally unprepared for it, believing, not unlike the suffragettes in the 1920s, that the legal ending of quotas and formal discrimination would solve everything.

Moreover, covert discrimination proved much more difficult to combat, because it often precluded collective action, which remains the only source of power for members of disempowered groups. Once each academic department could point to their token woman, chairs of committees and departments began denying hiring or promotion to women while proffering reasons for rejection other than gender, such as area of expertise. It took time to identify those subtle strategies, the euphemisms behind them, and the politics around them. For example, a workshop at NSF's - Advance Program in May $2005^{6}$, featured mock interviews by a theatrical troupe. Based on advice from faculty, the troupe showed how hiring and promotion committees were often dominated by their chairs, "alpha males" intent to hire young men, whom they regard as their own younger selves, even when the more qualified candidates were women. Most of us in the audience could recognize the tricks and their repeated patterns, but few could have predicted that cleverly disguised practices of subtle discrimination effectively enabled a few autocrats to quietly sabotage the institutions' formal efforts at achieving diversity with regard to women and other previously excluded groups, especially minorities.

The tensions caused by these covert actors ability to maintain the alienation between gender and technoscience (Stanley, 1993; Grint and Gill, eds. 1995; Haraway 2004; Bray, 2007; Wajcman, 2007) eventually exploded in the context of a public debate on the "under-representation of women in science" that raged world wide, but especially in the US, during 2005-06. It continues to this very day on a less intense scale, as articles, books, conferences, and reports continue to appear in response to the 2005-06 debate. The debate was triggered by Lawrence Summers, then President of Harvard University, while attempting to "explain" the under-representation of women in science at a conference on "Diversifying the Science and Engineering Workforce", sponsored by the Sloan Foundation and

\footnotetext{
${ }^{6} \mathrm{I}$ attended as a guest NSF-SGER PI; most attendees were Advance PIs, and NSF officers. See Advance 2005; SGER is a Program that provided "small grants for exploratory research"; it had been redefined in 2008 as two options, EAGER and RAPID, see details at nsf.gov.
} 
hosted by NBER, a think tank on economic policy based in Cambridge, MA (NBER, 2005). Several university presidents - Susan Hockfield of MIT, Shirley Tilghman of Princeton, and John Hennessy of Stanford, all scientists, also took public positions on that issue, albeit mild ones that focused on the future only. So did the American Sociological Association, the Association of Women in Science, and other organizations ${ }^{7}$.

The enormous resonance of the debate on the underrepresentation of women in science provided a significant context for current efforts to once again change the relationship between gender and technoscience. What are the real issues that must be dealt with to finally address this issue? Below, I compare Summers' three "explanations" for women's under-representation in science with the views of about 100 scholars of gender and technoscience, including historians, sociologists, and policy analysts.

\section{The Public Debate on the "Under-} Representation of Women in Science" in 2005-2006: A Pivotal Moment in the Recent History of Gender and Technoscience

Summers' first hypothesis stated that women refuse to work the long hours required by high-powered jobs. Despite its primary position in Summers' own ranking system based on explanatory power, his first hypothesis did not stir the public. The lack of evidence in its favor may have already reached the public. This "explanation" placed the responsibility for the under-representation of women in science on women's own preferences and choices (i.e. to set aside time for family-related responsibilities by avoiding occupations that demand a high investment of one's time) thus preempting any need for social policy to help women, indeed workers in general, to balance their work and family lives ${ }^{8}$ (Bailyn, 2002; Rosser, 2004).

\footnotetext{
${ }^{7}$ See details on various participants in the debate at people.brandeis.edu/ pninaga/sger including Hockfield, Tilghman and Henessy, 2005; Summers, L., 2005; Dean, 2005; ASA, 2005, among others.
${ }^{8}$ This approach of removing gender issues in the workforce from the purview of public policy parallels Summers' role in the deregulation of financial markets, an activity now understood to be part of the policies leading to the economic crisis of 2008. For the wider context of Summers' speech see the Proceedings of the conference at which he attempted to explain the under- representation of women in science, under NBER 2005;

Summers' third hypothesis, which mentioned discrimination as a cause for the under-representation of women, did not stir much fuss either, even though he listed the commonly accepted reason for gender inequality - discrimination - as the last and least pertinent explanation for the underrepresentation of women in science. Much as with the previous "explanation", the third hypothesis not only minimized the role of discrimination as a cause but further described it as being derivative of "socialization", or a process of adjustment toward a pervasive or "normal" state of affairs. This formulation cast discrimination as an inevitable outcome of ordinary socialization, thus removing it from the purview of regulation by social policy. Here the party to blame is society, whose process of socialization, presumably via the educational system, perpetuates gender discrimination. This hypothesis did not engage the public debate either, perhaps because discrimination was acknowledged, even if its actual impact was minimized (Etzkowitz and Gupta, 2006).

It was Summers' second hypothesis that triggered the public debate. That hypothesis stated that women were less able to attain high achievement in science, because they simply did not possess the aptitude required, a conclusion he extrapolated from the level of flatness of aptitude curves at both extremes. Some psychologists, on whose research Summers relied in his impromptu talk, interpret such curves to mean that there are fewer "innate" geniuses, as well as fewer "innate idiots" among women than among men. These findings are wholly irrelevant for understanding, let alone addressing the problem of the under-representation of women in science. Much as his other two hypotheses, the $2^{\text {nd }}$ hypothesis reflected Summers' strategy of substituting his limited background in science', as well as in history and sociology of gender and women in science ${ }^{10}$, for views of selected

\footnotetext{
${ }^{9}$ At a national conference organized by graduate science students at Harvard in April 2005, Summers revealed that he himself was a dropout from science, having left after the freshmen year. This revelation sheds new sinister light on the gender relationship in our society, which permits a male science dropout to lecture on women's alleged inability at a conference which included women scientists who unlike him spent a lifetime in science.

${ }^{10}$ At the April 2005 conference at Harvard's Maxwell-Dworkin Auditorium, I gave to Summers a copy of Uneasy Careers and Intimate Lives, Women in Science, I 789-1 979 (Rutgers University Press, 1987, 1989), a collection of essays by twelve authors mentioned as part of the citation to an award for outstanding research, with a page long letter suggesting that had he
}

ISSN: 07I 8-2724. (http://www.jotmi.org)

Journal of Technology Management \& Innovation (C) Universidad Alberto Hurtado, Facultad de Economía y Negocios 
colleagues from psychology and economics, views that remain uninformed by scholarship on gender and women in science. Such views may be part of a professional backlash, dressed up as "research", against the far reaching implications of the demands for gender equity that were at the center of the debate on the under-representation of women in science. Indeed, Summers' second hypothesis transformed the public debate into a public scandal, as the public was shocked to hear his rhetoric on innate limitations, especially since such views became discredited due to their past use in justifying discrimination on the basis of race or religion.

All these "explanations", eventually termed "hypotheses" by Summers supporters once it became clear that their empirical basis was highly dubious, were eventually addressed by the National Academy of Science Reports on "Bias and Barriers" (NAS 2006, 2009). The analysis embodied in those reports admitted the existence of structural barriers such as the "glass ceiling", barriers that proved to be more resistant to interventions of public policy than previously anticipated. Those reports also highlighted the persistence of both unconscious and conscious bias.

Since the NAS commission's social composition included many women and men experts in a variety of fields, as well as public policy figures, the reports achieved a measure of closure for the "debate that won't go away" (Dean 2005). Its recommendations are in a process of implementation, so it may take some time before we can assess whether they just put out the fire, or were able to address the more basic causes of persisting processes and outcomes of discrimination. After all, over its history, the NAS itself had been one of the most exclusionary organizations of science. It began to elect women in larger numbers only in the last two decades.

The public debate on the "under-representation of women in science" raged for over a year, between January 15, 2005 when the media learned of L. Summers' views on this topic and February 23, 2006 when he resigned his office as President of Harvard University, on the eve of a projected second vote of non-confidence by the Faculty of Arts and Science's assembly. During those 21 months or so, the

familiarized himself with this volume, he might have never stumbled so badly on the subject of gender and technoscience. Less than a year later, Summers resigned his office. debate was dominated by a variety of actors, starting with the university presidents who made a joint public statement to the media in mid-February 2005, as noted above; professional organizations, and eight NSF Advance grantees led by its Hunter College Pls who made a joint statement to the media (for details see people.brandeis.edu/ pninaga/sger). The national and international media began running articles, with Boston based newspapers such as The Boston Globe and the Harvard Crimson providing daily coverage. A great deal of opinion was also exchanged via e-mail, blogs, and websites. Suddenly, and somewhat unexpectedly, gender in technoscience became the rationale for a major public debate.

As a historian of science whose research included the "rescue" of women scientists from oblivion, I was particularly baffled by the total absence of a historical viewpoint in the debate, especially since the underrepresentation of women in science, like any human condition, has historical causes. Even though my colleagues in the sub-field of the history of women in science, technology, and medicine have been exploring the predicament of women and gender in the history of technoscience for the preceding two-three decades, none of the major "players" in this debate - university presidents, science organizations, NSF-Advance Pls, selfhelp organizations of women scientists, psychologists, and journalists, seemed to know of our work, let alone grasp the relevance of our long term perspective on the historical context of the under-representation of women in science.

\section{Invisible Experts: A Survey of Women and Gender in Technoscience (WGTS) Scholars on the Causes and Remedies for the "Under- Representation of Women in Science"}

In order to find out why a historical viewpoint was totally missing from such a crucial debate, I prepared and analyzed a survey that was filled online by about 100 scholars of women and gender in science, whether historians, sociologists, or policy analysts, out of 300 addressees ".

\footnotetext{
"I The survey's results can be viewed at people.brandeis.edu/ $\sim$ pninaga/sger. For a full discussion of the survey see the button "AHA-2007" there; for reasons of space not all the survey's questions are discussed here.
} 
The respondents included $66.6 \%$ of scholars who attended talks by WGTS colleagues; $57.1 \%$ who acknowledged being influenced by WGTS scholarship; and $41.7 \%$ who reviewed WGTS books. While $39.3 \%$ published articles in peer reviewed journals, $29.8 \%$ of the respondents wrote one or more books, while $21.4 \%$ edited or co-edited collection of essays in WGTS. $31 \%$ collaborated with WGTS scholars. Only $11.9 \%$ stated that they were not well acquainted with WGTS scholarship. It thus seems that about $40 \%$ of the respondents were WGTS scholars, the rest being colleagues in History of Science and STS fields who followed WGS scholarship.

On the issue of the respondent's own view regarding the persisting under-representation of women in science (Question 2), the first two hypotheses floated by Summers received a low \% with "lack of innate ability for high achievement" receiving $2.3 \%$ and "prioritizing of family issues, esp. children" receiving $21.6 \%$. However, Summers' third hypothesis on the prevalence of discrimination that derives from socialization (as a cause for the underrepresentation of women in technoscience), tied for the top third response when rephrased as "persisting gender bias and inequality in society at large" at $58 \%$.

It is significant that societal bias, which places the responsibility for women's predicament in science on society at large, tied with "denial of gender bias in science by scientists who believe that science is immune to all forms of bias because of its formal commitment to objectivity and truth", i.e. with attitudes prevalent among the scientists themselves that confuse science's abstract goals with a concrete social reality among its practitioners that differs from those abstract goals. To sum up, WGTS scholars believe that both scientists and society are equally responsible for the condition of under-representation of women in science.

However, the top response on causes for this condition went to "limited family-friendly work environment in universities and research institutes", a reason that pertains to technoscience as an employer that disregards the long societal tradition of gender inequality in child (and other family) care. By social tradition, women serve more often than men as the primary care takers of children, to the effect that women WGTS scholars consider lack of policies that enable flexibility with regard to family responsibilities, to be the single most important reason that forces women to leave scientific careers. However, this situation is peculiar to the US, where childcare is not available on an affordable basis as a basic social service, as is the case in welfare states.

Another leading reason for the condition of underrepresentation of women in science, ranked second in terms of respondents' selection at $60.2 \%$, is the “'evolution' of covert discrimination in academia, once overt barriers were removed". This is a particularly strategic area for further research since the rise of covert discrimination in the last two-three decades may well be the single most important reason for the failure to achieve gender parity in technoscience, once affirmative action legislation disposed of overt barriers and quotas.

Moreover, the prevalence and "success" of covert discrimination refutes the belief that remains a cornerstone of the NAS Reports, namely that the bias against women is mostly unconscious. If this were in fact true, it would disappear once those holding it were made aware of their unconscious bias. Covert discrimination remains to be studied and better understood either as a sophisticated adaptation of patriarchy in technoscience to the challenge of affirmative action; or as the product of unintended consequences in a technoscience system that remains predominantly male dominated and lacks incentives to share power with members of the other gender. Covert discrimination found the first generation of technoscience educated women and their supporters totally unprepared, leading eventually to the glass ceiling phenomenon. Its impacts included: slow advancement for women, recruitment without retention, lower pay for same work, lesser lab and office space, and so on ${ }^{12}$.

Given the richness of historical scholarship on women and gender in technoscience since the 1970s, scholarship that proved beyond any doubt the numerous contributions of women to science despite exclusion, discrimination and gender inequality, Question 3 addressed reasons for the invisibility of such scholarship in the debate on the underrepresentation of women in science, a debate which failed

\footnotetext{
12 MIT, "A Study on the Status of Women Faculty in Science at MIT", The MIT Faculty Newsletter, vol. XI, 1999, No. 4; "MIT vows to counter gender bias", The Boston Globe, 3-20-2002, A-20. Hopkins, Nancy, Lotte Bailyn, Lorna Gibson, and Evelynn Hammonds, An Overview of Reports from MIT Schools. (MIT, 2002) This Report provided pay back to female faculty.
} 
to make use of pertinent findings from the history of women and gender in science.

A key reasons for the invisibility of WGTS in the 2005-06 debate pertained to the tendency of policy makers to limit themselves to input from quantitative social sciences (economics, psychology, sociology) and to the parallel lack of a tradition of influencing policy among historians $(57 \%$ and $55.8 \%$, respectively). But a no less important reason pertained to the status of WGTS itself as a new field. (57\%) Question 5 thus inquired into the obstacles faced by those who wish to better establish WGTS in academia.

By far, the largest \% of respondents (63\%) believes that there is tension between WGTS as an interdisciplinary field and the disciplinary agendas of scholars who practise it in conjunction with their formative discipline. This topic remains to be further researched, since WGTS can best flourish in a context of harmony between fields such as history, sociology, philosophy, and women's studies, rather than in separation from each other. It is significant however that $43 \%$ believe that there is intellectual resistance to the paradigm change implied by WGTS scholarship.

Though women's marginalization from positions of power is viewed as a source of marginalization for the WGTS field $(40.5 \%)$, which is practiced mainly by women, most respondents do not believe that tokenism (the practice of hiring one woman as a showpiece to counteract charges of gender bias) and cultural bias (e.g. age, sexual orientation) are major reasons for WGTS's modest status in academia. These responses remain to be followed up, since WGTS status has changed over time, from high visibility in the late 1980s, when a session on the history of women in science was reported in Science Magazine next to its Presidential Address; the History of Science Society created a special prize for excellence in scholarship on women and gender in science; and a new book Series on "Lives of Women in Science" had been created by Rutgers University Press, to an all time low in the decade preceding the 2005 debate. Ironically, these changes in the fortunes of WGTS as a meta-scientific domain, do not parallel those in the world of science, where long persisting gender bias mutated into a display of gender parity during the 2009 Nobel Ceremonies, as illustrated in the next section.

\section{From Gender Filtering of Public Memory to Parity in the Nobel Prize: Half a Century of Slow Changes in the Public Perception of Women Scientists}

The 2009 Nobel Prizes had enormous symbolic value, but not only because of their numerical gender parity, awarding five women and five men laureates, as noted above. Of great symbolic value was the inclusion of two women in the Nobel Prize for Physiology/ Medicine, Elizabeth Blackburn (1947-) and her then Ph.D. student Carol Greider (196I-).

This was the first time that collaboration between women, as well as across generations, was recognized, thus signifying that the presence of women at the highest scientific level is not an ephemeral phenomenon, but rather a reproducible one. Moreover, since the laureates for each Nobel category are limited to three, women formed the majority of laureates in a given field for the first time (The third laureate, Jack Szostak, was also a former collaborator of Elizabeth Blackburn; (www.nobelprize.org/2009)).

In addition to aspects such as a "first" collaboration of women, or women laureates being a majority in a field, Greider, the "youngest" among all 2009 laureates ,who was awarded the Prize for work done as a graduate student in the mid-1980s, , has remained visibly youthful. Such a youthful looking female laureate is a profoundly more viable role model than older women laureates, who often tend to deny that their beloved system of science may have discriminated against them, even though they are often emotionally, as well as visibly, scarred by years of discrimination and withheld recognition.

Moreover, Greider conveyed the new generation's compatibility with gender and technoscience by bringing to Stockholm her two children, a girl age 8 and a boy age II, a great rarity at the Nobel ceremony. While most men laureates rarely bring their children to such events because they do not consider them essential to their professional identity, women awardees rarely have them. As the 2009 Nobel laureate in economics Elinor Ostrom readily admitted, she had no time for marriage and children, if she wished to focus on being the first woman Nobel laureate in economics. 
Even when a rare woman Nobel Laureate did manage to have a family life including both a long marriage to one husband and children, as the 1964 sole Nobel Laureate in Chemistry, Dorothy C. Hodgkin did, her male colleagues invariably filtered her public memory through what they remembered more clearly than her science, namely her gender, class, and race. Women scientists were the only ones capable to provide a public memory of her that focused first and foremost on her science and only later on her commitments in the realms of gender, race, or class. It is worthwhile to dwell on how Hodgkin's public memory had been shaped by her gender, especially since it took science almost half a century to find another women Nobel laureate in chemistry (Ada E. Yonath in 2009; during this period of almost half a century there were about half a dozen women Nobel Laureates in Physiology, still a very small percentage often I-2 per decade, while the maximum laureates per decade is 30 per field).

Dorothy Hodgkin (1910-94) received the 1964 Nobel Prize in chemistry for her solution of the structure of vitamin B-12 in the mid- and late-1950s, at a time when that 110 atom molecule was the largest ever to be solved. It also became a turning point in the chemists' acceptance of X-ray crystallography as a method that could anticipate traditional synthetic methods. She was also involved as lab director in the solution of the structure of penicillin during WW2 and insulin in 1969, among other molecules of biological interest. Her main technique, x-ray crystallography, combines aspects of physics, chemistry, and mathematics, while the molecules she focused on had considerable biological, medical, or physiological functions. Therefore, her work can be taken as representative of the entire spectrum of technoscience.

Hodgkin's career reflects a blend of the challenges and successes faced by women born prior to WWI. Women like Hodgkin became students a decade after women were granted the vote, and only a couple of years after her home university, Oxford, decided to confer degrees upon women. Fortunate to have timed her entry into the field well, Hodgkin, who became a don at Somerville College in 1936, was allowed to retain that position upon getting married in 1937 because the rules governing women's academic employment were relaxed in the late 1930s (on Hodgkin's career see "Oxford 2008", people.brandeis.edu/ pninaga).
During WW2 Hodgkin focused on the structure of penicillin, just isolated at the time in the Department of Pathology at Oxford, eventually solving it with a team composed of women and refugees by 1945. That feat made Hodgkin one of the first women to be accepted as a Fellow of the Royal Society after WW2. Also at that time, she successfully competed for the position of Reader at Oxford, holding it throughout the 1950s. Since a regular Professorship was not forthcoming, she obtained a Research Professorship from the Royal Society on the strength of her work on vitamin B-12 structure during the 1950s, work which later won her the 1964 Nobel Prize. Other honors followed, including the O.M. in the late 1960s and the Chancellorship of Bristol University. This pattern is roughly comparable to the careers of successful men in her field, though it is not difficult to spot the role of gender in preventing her from occupying higher positions at Oxford, as did younger men she mentored.

It thus may come as a surprise that in the cultural memory of technoscience, i.e. in commemorative discourses pronounced on the occasion of her retirement at age 70 or after her death at age 84 , her contributions were invariably viewed by male scientists through the prism of major social categories such as gender, class, or race. Women scientists were the only ones who related to her achievements in science in a straightforward manner, while illuminating her specific contributions, whether scientific or technical, in detail. For example, European male scientists emphasized her "gentle" demeanor, "happily married" status (with three children), "intuition", and family atmosphere in the lab. All these "compliments" are not usually paid to male scientists. They are also superficial and incorrect on closer inspection. It thus seems that in Hodgin's own (European) civilization, gender overrode science in her colleagues' efforts to convey her legacy. They could not help but seeing her as a woman scientist with her gender filtering the public memory of her male colleagues.

By contrast, Indian male scientists emphasized her "spirituality" as an activist devoted to spreading her brand of science to every nook and corner of the Indian subcontinent, further seeing her as a combination of Gandhi and Mother Theresa. Hodgkin's interest in India stemmed from post-colonial nostalgia common among Britons who grew up in families outposted in the British Empire. Her interest in spreading her field in India occurred in a 
context of competition with other, often British, scientists. Still, her Indian scientist colleagues, for whom her membership in the nation or "race" which colonized India mattered most, and evidently more than her gender, chose to remember her in hybrid cultural terms. Those terms combined the spirituality of India's founding father, who also made a point of bringing his personal message to every nook and corner of the country, and that of Mother Theresa, a self-sacrificing nun from Europe who devoted her life to the Indian needy, much as Hodgkin was attentive to the Indian needy in science.

If gender and race served as the key prisms for European versus Indian scientists in creating a cultural memory of Dorothy Hodgkin, then Chinese scientists can be said to have focused on class ideology as a state policy in conveying her legacy to them. They viewed Hodgkin primarily as a scientific ambassador, willing to report their findings at International Congresses at a time they could not travel outside the Second World of Communist countries, as well as sharing news from world science with them. Hodgkin did so mainly in her capacity as President of Pugwash during 1975-85. Pugwash received the Nobel Prize for Peace in 1995, a year after Hodgkin's death. She thus came rather close in matching Linus Pauling's record as a Nobel Laureate for both Chemistry and Peace. Still, when these two died in 1994, Pauling was widely eulogized, while Hodgkin's status as a grandmother often took precedence in her obituaries.

The only scientists who cared primarily about Hodgkin's precise contributions to science were the women scientists. They highlighted the technical challenges she faced due to the unknown type of rings or unusual symmetries found in the compounds she selected to solve, her strategy of successfully solving increasingly larger and more complex structures. They also emphasized her methods of promoting women, and scientists from the Third and Second Worlds, both male and female, without antagonizing the establishment, whether in science or at Oxford.

The study of the construction of a public memory for Dorothy Hodgkin in Europe, India, and China, summarized here, suggests that gender remains the most powerful framework for relating to women by the men who count most in the reward system of technoscience, namely men from the once so-called "First World". If a superaccomplished scientist such as Hodgkin, who had all the possible advantages in a scientist's career (or the "right" background in terms of class, race, religion, region, nationality, new research area, good career timing, younger female siblings, a matrilocal marriage, academic inlaws, etc.) was subjected to gender bias by those reflecting on her legacy, then beginner women technoscientists who in addition to their gender may also have other "liabilities", such as race, class, age, foreign nationality, non-traditional families, etc. must develop strategies to deal with this bias, particularly when it is covert.

\section{Conclusions}

The last five years saw a major shift in the public awareness of the relationship between gender and technoscience, with gender parity becoming for the first time a matter of extensive public debate, cultural symbolism, and policy intervention. As suggested in sections 2 and 3 , the mobilization by the public debate on the under-representation of women in science of a wide variety of actors, ranging from women scientist activists such as Nancy Hopkins of MIT, presidents of several leading research universities, and the National Academies of Science, Engineering and Medicine, to professional and self-help organizations, governmental funding agencies, scholars in meta-scientific fields, journalists, and independent bloggers, is evidence that the nexus of gender and technoscience is never far removed from the center of public debate in the global village. Though radical change in the realm of policy for gender parity remains to be implemented on a large scale, the new awareness of this issue's importance, as documented in this paper, has already shifted the terms of public debate beyond the toleration of gender bias.

The interaction of gender and technoscience, though increasingly understood as mutually transformative, theoretically challenging, and historically changing (Wajcman, 2007; Bray, 2007, Haraway, 2004, Rothschild, ed. 1983, Cowan, 1983; Stanley, 1993; Lerman et al, eds, 2003; Oudshoorn, 2004), remains a major challenge for scholars of gender and technoscience in the $2 \mathrm{I}^{\text {st }}$ Century. The shift away from technoscientific determinism (of gender, among other social categories) and gender essentialism (toward gender as performativity) opens exciting new analytic opportunities, especially if the key issue of power is prioritized. Technoscience may thus emerge as an avenue for gender parity, while gender may 
transform technoscience through a more humane source of humanpower.

While the study of gender grew enormously in complexity to include not only the construction and impact of femininities and masculinities, but also of transgendered identities, the study of technoscience had become a huge, comparative and transnational nexus of interdisciplinary and post-colonial potentialities (Leurs, 2009). Late modernity will no doubt witness "immodest" and farreaching new interactions between these two, ever malleable, systems of meaning, power, and social order at the very epicenter of our civilization. The ever newer multiplicities of both gender and technoscience identities signal the plausibility of a new era of greater agency for all, flexible re/structuration, decreased domination, and ever growing equality.

\section{References}

ABIR-AM, P.G. (2010). What's in a session. History of Science Society Newsletter, 35(I) January, 24-25.

(1996). Women in Modern Scientific Research: A Historical Overview. World Science Report. UNESCO, Paris, 348-59. (also in French, Spanish, Chinese)

(1992). Science policy or social policy for women in science: Lessons from historical case studies. Science and Public Policy, 19(4) April, I I-I2.

ABIR-AM, P. G., Outram, D. (Eds.), (1987, 1989). Uneasy Careers and Intimate Lives, Women in Science, 1789-1979. Rutgers University Press, New Brunswick/NJ.

ADVANCE (2005). NSF Program, Discussion on May 19\&20. (www.advance-portal.net)

BAILYN, L. (1993). Breaking the Mold: Women, Men, and Time in the New Corporate World. The Free Press, New York.

BIX, A.S. (2004). A History of Women's U.S. Engineering Education, NWSA Journal, I6(I) 27-49.

BRAY, F. (2007). Gender and Technology, Annual Review of Anthropology, 36, 37-53.
CORNELIUSSEN, H.G. (2009). Disrupting the Impression of Stability in the Gender-Technology Relation, $5^{\text {th }}$ European Symposium on Gender \& ICT, March 2009, University of Bremen, Germany.

COWAN, R.S. (1983). More Work for Mother: The Ironies of Household Technology from the Open Hearth to the Microwave. Basic Books, New York.

DEAN, C. (2005). Theorist Drawn into Debate 'That Will Not Go Away?', The New York Times, 04-12-2005.

ETZKOWITZ, H., Gupta, N. (2006). Women in Science: A Fair Share? Minerva, 44, I85- 199.

ETZKOWITZ, H. et.al. (2000). Athena Unbound: The Advancement of Women in Science and Technology. Cambridge University Press, New York.

FISCHER, I.K. (2005). Geodesy? What's That? I Universe, Inc., New York.

FOX, M.F. Johnson, D.G., Rosser, S.V. (eds.) (2006). Women, Gender, and Technology. University of Illinois Press, Urbana, Illinois.

FRIEDMAN, R.M. (200I) The Politics of Excellence. Behind the Nobel Prize in Science. Henry Holt and Company, LLC, New York.

GREEN, A., Troup, K. (1999). The Houses of History. A Critical Reader in $20^{\text {th }}$ Century History and Theory. New York University Press, New York.

GRINT K., Gill, R. (eds.) (1995). The Gender-Technology Relation: Contemporary Theory and Research. Taylor \& Francis, London.

HARAWAY, D.J. (1989) Primate Visions: Gender, Race, and Nature in the World of Modern Science. Routledge, New York and London.

------ (1997) Feminism and Technoscience. Routledge, New York and London.

- (2004). The Haraway Reader. Routledge, New York and London. 
HOWES, R.H., Herzenberg, C.L. (1999). Their Day in the Sun: Women of the Manhattan Project. Temple University Press, Philadelphia.

KELLER, E. (1985). Reflections on Gender and Science. Yale University Press, New Haven, CT.

KOHLSTEDT, S.G., H. Longino (eds.) (1997). Women, Gender and Science, New Directions. University of Chicago Press, Chicago. (also as Osiris I2)

LERMAN, N.E, et al, (eds.) (2003). Gender and Technology: A Reader. Johns Hopkins Univ. Press, Baltimore.

LEURS, K. (2009). Performing gender and etrhnicity in socio-cultural networks: entangling feminist technoscience and post-colonial theory. feministtechnoscience.se/journal. [Accessed March 22, 2010]

MERCHANT, C. (1980). The Death of Nature: Women, Ecology, and the Scientific Revolution. Harper and Row, New York.

MCGRAYNE, S.B. (1998). Nobel Prize Women in Science. Their Lives, Struggles and Momentous Discoveries. Citadel Press, Secaucus/ N.J. $2^{\text {nd }}$ edition.

NATIONAL ACADEMY OF SCIENCE (2006, 2009). Beyond Bias and Barriers. NAS Press, Washington, D.C: free executive summary at http://www.map.edu/catalog/ II74I.html) [Accessed October 4, 2006]

NATIONAL BUREAU OF ECONOMIC RESEARCH (2005). Diversifying the Science \& Engineering Workforce, 2 volumes. (Proceedings of a Conference, I/I4-15, 2005; Cambridge, MA)

NATIONAL RESEARCH COUNCIL (199I). Women in Science and Engineering: Increasing their numbers in the 1990s. National Academy Press, Washington, D.C.

NATIONAL SCIENCE FOUNDATION CONFERENCE REPORT (1997). Women \& Science: Celebrating Achievements, Charting Challenges. National Science Foundation, Arlington, VA.

OUDSHOORN, N, (2003). The Male Pill, A Biography of a Technology in the Making. Duke University Press, Durham, N.C.
OUDSHOORN, N., et a.l (2004). Configuring the user as everybody: gender and design cultures in information and communication technologies. Science, Technology and Human Values, 29(I) 30-63.

PYCIOR, H.M., Slack N.G., Abir-Am, P.G. (eds.) (1996). Creative Couples in the Sciences. Rutgers University Press, New Brunswick/N.J.

RAYMAN, P., et al. (eds.) (2008). Working WISE: Intergenerations Voices Advancing Research and Policy for Women in Science, Technology, Engineering and Mathematics Univ. of Mass. Lowell Center for Women and Work, Lowell, MA.

ROTHSCHILD, J. (ed.) (1983). Machina ex dea: Feminist Perspectives on Technology. Pergamon Press, New York.

ROSSER, S, V. (2004). The Science Glass Ceiling: Academic Women Scientists and the Struggle to Succeed. Routledge, New York.

ROSSITER, M. W. (1982) Women Scientists in America, Struglles and Strategies, 1880-1940 Johns Hopkins University Press, Baltimore.

----- (1995). Before Affirmative Action, Women Scientists in America, 1940-1972. Johns Hopkins University Press, Baltimore.

SCHIEBINGER, L. (1989). The Mind Has No Sex? Women in the Origins of Modern Science. Harvard University Press, Cambridge, MA.

SMITH-DOERR, L. (2006). Women's Work, Gender Equality vs. Hierarchy in the Life Sciences. Rinner, Boulder/CO.

STANLEY, A. (1993). Mothers and Daughters of Invention: Notes for a Revised History of Technology. Rutgers University Press, New Brunswick, NJ.

VALIAN, V. (1999). Why So Slow: The Advancement of Women. The M.I.T. Press, Cambridge, MA.

WAJCMAN, J. (2007). "From Women and Technology to Gendered Technoscience"', Information, Communication, and Society, 10(3) 287-298. 


\section{About the Author}

Dr. Pnina Geraldine Abir-Am is a historian of science who has published widely on the history of women and gender in science, the history of molecular biology, and the history of public memory. She is recipient of an award from the US History of Science Society for outstanding research in the history of women in science and has co-edited Uneasy Careers and Intimate Lives: Women in Science, I789-1979 (1987, 1989) Creative Couples in the Sciences, (1996) and Commemorative Practices in Science: Historical Perspectives on the Politics of Collective Memory (2000). She began serving a four year term as Vice-President of the International Commission on Women in the History of Science, Technology and Medicine in July 2009. Recent work focuses on the role of gender in the misallocation of credit in science, and on the public memory of DNA. 